\title{
Ban on menthol cigarettes: European Union member states shall prohibit the placing on the market of tobacco products with a characterising flavour
}

\author{
European Network for Smoking and Tobacco Prevention ${ }^{1}$
}

A European Union (EU) wide ban on menthol cigarettes sales went into effect on 20 May 2020 following the Directive 2014/40/EU of the European Parliament and of the Council of 3 April 2014 on the approximation of the laws, regulations and administrative provisions of the Member States concerning the manufacture, presentation and sale of tobacco and related products, repealing Directive $2001 / 37 / \mathrm{EC}^{1}$.

The regulation on characterising flavours is one of the key changes for tobacco products sold in 27 EU Member States and United Kingdom under the European Tobacco Products Directive (TPD), which came into force in 2016. As stated in the European Commission's press release:

'Cigarettes and roll-your-own (RYO) tobacco products may no longer have characterising flavours such as menthol, vanilla or candy that mask the taste and smell of tobacco. In the case of products with more than a 3\% market share (e.g. menthol), the ban will apply as of 2020'.

Cigars, cigarillos and snus are exempt from this ban².

\section{The tobacco products directive}

The TPD aims to align tobacco control legislation across Member States to facilitate meeting its obligations under the World Health Organization Framework Convention on Tobacco Control (WHO FCTC) of May $2003^{1}$. Article 7 of the TPD on the regulation of ingredients states that:

'Member States shall prohibit the placing on the market of tobacco products with a characterising flavour'.

In developing the legislation, the EG considered a large repository of scientific evidence in order to better protect its citizens from the devastating effects of tobacco use ${ }^{3}$.

Flavouring is prohibited also in filters, papers, packages, capsules or any technical features allowing modification of the smell or taste of the tobacco products concerned or their smoke intensity ${ }^{1}$. The TPD bans characterising flavours 'other than that of tobacco', meaning that it is 'an added component that cannot be found in natural tobacco leaves'.

The Directive's Article 7, 'Regulation of ingredients', establishes the common ground of implementation for its Member States, mentioning the applicability on the products and the exceptions regarding the adjacent tobacco-free accessories $^{1}$. To support its implementation, the Commission has adopted two separate normative Acts displaying the mechanisms for determining flavoured products:

- Commission Implementing Regulation (EU) 2016/779 of 18 May 2016 laying down uniform rules in regard to the procedures for determining whether a
AFFILIATION

1 European Network for Smoking and Tobacco Prevention, Brussels, Belgium

CORRESPONDENCE TO European Network for Smoking and Tobacco Prevention, Chaussee d'Ixelles 144b, Brussels, 1050, Belgium. E-mail: secretariat@ ensp.org

KEYWORDS

tobacco products ban, menthol cigarettes, flavours ban, European Union

Received: 18 June 2020

Accepted: 18 June 2020 
tobacco product has a characterizing flavour ${ }^{4}$.

- Commission Implementing Decision (EU) 2016/786 of 18 May 2016 laying down the procedure for the establishment and operation of an independent advisory panel assisting Member States and the Commission in determining whether tobacco products have a characterizing flavour ${ }^{5}$.

\section{Evidence-based decision}

According to the $\mathrm{WHO}$, the tobacco epidemic is one of the biggest public health threats the world has ever faced, resulting in more than 8 million deaths each year. More than 7 million of those deaths are the result of direct tobacco use while about 1.2 million are the result of non-smokers being exposed to secondhand smoke (SHS) ${ }^{5}$. Moreover, the economic costs of tobacco use are substantial and include significant healthcare costs for treating the diseases caused by tobacco use as well as the lost human capital that results from tobacco-attributable morbidity and mortality ${ }^{6}$.

Research shows that a ban on characterising flavours of tobacco products will contribute to the general public's health by discouraging people to start smoking or encouraging smokers to quit. According to the latest Eurobarometer report (2017), 8\% of EU smokers smoke menthol cigarettes and $7 \%$ other flavoured cigarettes ${ }^{7}$. These numbers suggest that a ban on characterising flavours is likely to directly affect at least one in ten smokers. Within the Members States, menthol cigarettes are most widely consumed in Finland (24\%) and Denmark (20\%) while younger people are slightly more likely to smoke menthol cigarettes (11\%) than the average person ${ }^{7}$.

Additionally, researchers have found that menthol, as an active compound interacting with other tobacco components, may not only damage or kill cells, but may also worsen cardiovascular disease compared to non-menthol cigarettes ${ }^{8}$. It was also found that flavoured cigarette use is more common among youth and new smokers ${ }^{9}$.

\section{Enforcement of the directive}

The ban also prohibits capsulated cigarettes or rollyour-own tobacco, including 'click on', 'click \& roll', and 'dual', which are mechanisms for adding flavour to the product, separate from the cigarette itself.
However, the directive does not include mentholated papers and filters sold separately from RYO tobacco products. There is no sell-through period of menthol cigarettes, meaning that from 20 May 2020 sales are forbidden. Retailers could only sell their remaining stock until that due date ${ }^{1}$.

\section{ENSP monitoring activities}

The European Network for Smoking and Tobacco Prevention (ENSP), through its national members and partners, will support and monitor the full implementation of the characterising flavours ban under Directive 2014/40/EU. As the due date for the flavoured tobacco products was approaching, the tobacco industry started encouraging users to switch to flavoured products exempt from the TPD, such as cigarillos, cigars, smokeless tobacco products, electronic cigarettes, and heated tobacco products.

Other industry tactics include, cardboard strips that can be inserted into a cigarette pack or pouch of rolling tobacco to impart a peppermint aroma and cigarillos (small cigars that are exempt from the ban) with capsules that release menthol at the push of a button. In addition, U.K. Imperial, the maker of Rizla rolling paper, has already been selling menthol filter tips for loose tobacco for years and now plans to offer these products in other European countries ${ }^{10}$.

Given that many European countries outside of the EU have not banned flavoured cigarettes, there is the worrying possibility that EU smokers will smuggle in or buy illegal menthol and other flavoured cigarettes. Illicit trade of tobacco products is a serious crime and all states must concentrate their efforts to combat it ${ }^{11}$.

ENSP is also committed to supporting the ban on characterising flavours by enhancing its continued efforts to improve tobacco dependence treatment through training of healthcare professionals via e-learning, advocating etc.

\section{REFERENCES}

1. Directive 2014/40/EU of the European Parliament and of the Council of 3 April 2014 on the approximation of the laws, regulations and administrative provisions of the Member States concerning the manufacture, presentation and sale of tobacco and related products and repealing Directive 2001/37/EC. Official Journal of the European Union. 2014;127(1):1-38. https://eur-lex.europa.eu/legalcontent/EN/TXT/?uri=OJ\%3AJOL_2014_127_R_0001. 
Accessed June 18, 2020.

2. European Commission. 10 key changes for tobacco products sold in the EU. https://ec.europa.eu/commission/ presscorner/detail/en/IP_16_1762. Accessed May 15, 2020.

3. Mapping of best practices and development of testing methods and procedures for identification of characterising flavours in tobacco products: RfS Chafea/2014/health/19, Contract no 20146202. https://ec.europa.eu/health/sites/ health/files/tobacco/docs/hetoc_frep_en.pdf. Accessed May 15,2020

4. Commission Implementing Regulation (EU) 2016/779 of 18 May 2016 laying down uniform rules as regards the procedures for determining whether a tobacco product has a characterising flavour. Official Journal of the European Union. 2016;131:48-54. https://eur-lex.europa.eu/legal-content/ $\mathrm{EN} / \mathrm{TXT} / \mathrm{PDF} /$ ?uri=CELEX:32016R0779\&from=EN. Accessed May 15, 2020.

5. Commission Implementing Decision (EU) 2016/786 of 18 May 2016 laying down the procedure for the establishment and operation of an independent advisory panel assisting Member States and the Commission in determining whether tobacco products have a characterising flavour (notified under document C(2016) 2921). Official Journal of the European Union. 2016;131:7987. https://eur-lex.europa.eu/legal-content/EN/TXT/ $\mathrm{PDF} /$ ?uri=CELEX:32016D0786\&from=EN. Accessed May 15,2020

6. World Health Organization. Tobacco key facts. https://www. who.int/news-room/fact-sheets/detail/tobacco. Published May 27, 2020. Accessed June 15, 2020.

7. European Commission. Special Eurobarometer 458: Attitudes of Europeans towards tobacco and electronic cigarettes. 2017. doi:10.2875/245123

8. Hoffman, Allison C. The health effects of menthol cigarettes as compared to non-menthol cigarettes. Tob Induc Dis. 2011;9(1):S7. doi:10.1186/1617-9625-9-S1-S7

9. European Commission. SCENIHR: Addictiveness and attractiveness of Tobacco Additives. https://ec.europa. eu/health/scientific_committees/emerging/docs/ scenihr_o_031.pdf. Published November 12, 2010. Accessed May 15, 2020.

10. Gretler C. Europe's Menthol Ban Has Tobacco Firms Thinking Outside the Pack. Bloomberg. https://www. bloomberg.com/news/articles/2020-02-05/eu-mentholban-tobacco-firms-offer-alternatives-to-cigarettes. Published February 5, 2020. Accessed May 15, 2020.

11. WHO Framework Convention on Tobacco Control. Protocol to Eliminate Illicit Trade in Tobacco Products. https://apps.who. int/iris/bitstream/handle/10665/80873/9789241505246_ eng.pdf?sequence=1. Accessed May 15, 2020.

\section{CONFLICTS OF INTEREST}

The authors have completed and submitted the ICMJE Form for Disclosure of Potential Conflicts of Interest and none was reported.

FUNDING

There was no source of funding for this research.

PROVENANCE AND PEER REVIEW

Commissioned; internally peer reviewed. 